\title{
Electrophoretic evidence of reproductive isolation between two varieties of the moss, Climacium americanum
}

\author{
Jonathan Shaw, \\ Thomas R. Meagher and \\ Pamela Harley
}

Department of Botany, Duke University, Durham, North Carolina 27706, U.S.A.

\begin{abstract}
Two hundred and twenty individuals of the moss, Climacium americanum, from three localities in the Piedmont of North Carolina were sampled for a study of electrophoretically detectable genetic variation. Eight enzymes ( $A C P$, $A D H, E S T_{f}, G O T, P E R, P G I, P G M$, and $\left.S O D\right)$ were assayed and only two (GOT, SOD) were monomorphic at all three localities, in spite of the extreme rarity of sexual reproduction in this species. Although the var. kindbergii has generally been considered a form of $C$. americanum induced by submersion in water, there was a strong correlation between enzyme phenotypes and morphological characters distinguishing the two varieties of $C$. americanum. These data suggest that there is linkage disequilibrium among the loci coding for $A C P, P G M$, and $P G I$, and between these loci and those controlling several morphological characters that distinguish the two varieties of $C$. americanum.
\end{abstract}

\section{INTRODUCTION}

The Climaciaceae is a small family of mosses consisting of four species in a single genus, Climacium. In North America, the genus is represented by two species, $C$. americanum Brid. and $C$. dendroides (Hedw.) Web. and Mohr. Climacium dendroides has a circumboreal range and is widespread in north-temperate North America, whereas $C$. americanum is endemic to the eastern United States. Species of Climacium are among the most robust and recognizable of temperate mosses, characterised by below-ground thizomatous stems and erect, branched, dendroid secondary branches. The common name, tree moss, is descriptive of the dendroid growth form typical of species in the genus. The production of sporophytes is very rare in both species of Climacium, apparently a result of most natural populations being unisexual, producing only female gametangia (Bedford, 1938).

Climacium americanum varies in growth form from erect and strongly dendroid to elongate and trailing with an irregular branching pattern (fig. 1). The variation in growth form of $C$. americanum has been observed to be dimorphic and is correlated with habitat: plants are generally dendroid in mesic forests and are trailing with irregular branching on rocks in small streams or in swamps.
However, the ecological correlation is far from absolute and both forms sometimes occur in what appears to be the same habitat.

The dimorphism in growth habit in Climacium americanum has resulted in various systematic treatments of the species. Renauld and Cardot (1890) described C. americanum var. kindbergii based on plants from Louisiana and Massachusetts having more distant leaves and shorter, oblong leaf cells as compared to the var. americanum. Although Renauld and Cardot did not discuss growth form when they described the var. kindbergii, the varietal epithet has since become associated with forms of C. americanum characterized by irregular, nondendroid branching. Grout (1901) raised the var. kindbergii to specific rank, arguing that $C$. kindbergii differs in geographic distribution as well as morphology. In 1904, Cardot and Theriot, however, described $C$. americanum var. pseudokindbergii from Missouri, remarking that it has the growth form of $C$. kindbergii but the areolation of C. americanum, and argued against considering them two species. On the basis of additional observations, Cardot and Theriot (1906) argued that $C$. americanum and $C$. kindbergii intergrade to a significant extent.

More recently, C. kindbergii has been considered to be an environmentally induced variant 


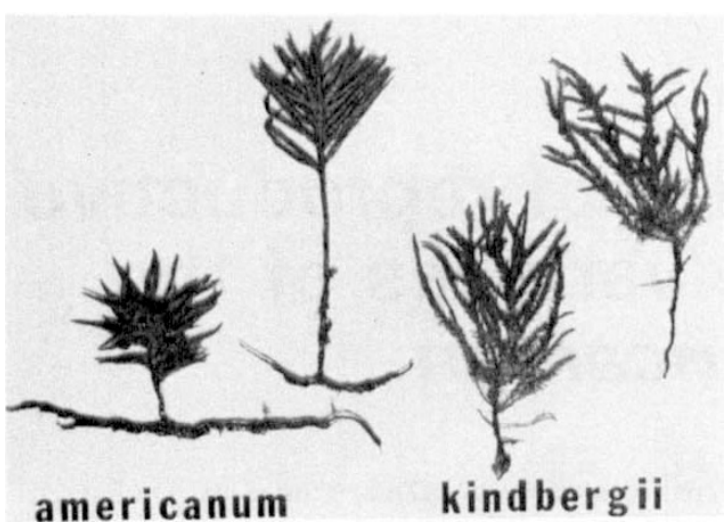

Figure 1 Morphological differences between Climacium americanum var. americanum (left) and var. kindbergii (right).

of C. americanum (e.g., Crum and Anderson, 1981). Horton and Vitt (1976) and Crum and Anderson (1981) interpreted C. kindbergii as a phenotypic expression of $C$. americanum induced by submersion in water during all or part of the growing season. Shaw (in press) grew forms referable to $C$. americanum and $C$. kindbergii under controlled environmental conditions and found only weak evidence for discontinuity between them. The degree of tolerance to desiccation varied among populations but did not correlate with habitat or morphology. Shaw presented experimental evidence suggesting that the degree of desiccation tolerance was more closely related to environmental pretreatment than to genetic differences among plants.

This study of electrophoretically detectable variation was initiated in order to assess the level of genetic variation in C. americanum, a species in which sexual reproduction appears to be extremely rare, and to determine whether variation in enzyme phenotypes correlates with growth form variation corresponding to the vars. kindbergii and americanum.

\section{MATERIALS AND METHODS}

Collections were made at three localities in the Piedmont of North Carolina near the city of Durham. The first locality was along the Eno River in Durham County where the river crosses U.S. Route 70, about 12 miles northwest of Durham. Climacium americanum is extremely common in the floodplain between two and 15 feet from the river bank, and forms discreet clumps of irregular size and shape. Floodplain plants invariably exhibit the dendroid growth form. However, the species also occurs on rocks in a small stream in a narrow ravine that drains into the Eno River. All plants observed in the latter habitat are of the non-dendroid, or "kindbergii", form. The small stream varies seasonally in flow rate but some water is apparently always present and many of the clumps of Climacium were at least partially submerged. Sixty plants were collected along a transect in the floodplain parallel to the Eno River and sixty were collected along a transect in the seasonal stream. Only a single plant was collected from each clump encountered along the transects.

At the remaining two localities, plants conforming to the vars. americanum and kindbergii grew in closer proximity to one another although any particular clump exhibited either dendroid or nondenroid growth, i.e., the two forms did not grow intermixed in the same discreet clump. Forty plants were collected in the floodplain of New Hope Creek, a small river in the Duke Forest about 3 miles southeast of Durham in Durham County. Again, collections were made at least one meter apart to avoid multiple collections from the same clump. Plants characterised by dendroid versus nondendroid growth were sampled as they were encountered along the transect. Sixty plants were collected from a similar floodplain habitat along the Flat River, approximately 18 miles north of Durham in Person Co. Plants of the two contrasting growth forms occurred as discreet clumps and were sampled as encountered along the transect. At both New Hope Creek and along the Flat River, plants were subjectively classified as var. kindbergii or var. americanum as they were collected. Intermediate forms were noted as such.

Plants were refrigerated in a moistened state for 2-3 days prior to enzyme extraction. Several extraction buffers were tried in a preliminary study, including those described by Kelley and Adams (1977) for sequestering phenolic compounds released by Juniperus leaves, and by Soltis et al. (1983) for extracting enzymes from gametophytes of ferns and fern allies. These extraction buffers did not improve the results obtained by extraction in a simpler $0 \cdot 1 \mathrm{M}$ tris- $\mathrm{HCl}(p \mathrm{H} 7 \cdot 2)$ buffer with 0.5 per cent mercaptoethanol so that the latter was used exclusively in this study. Extractions were tried with and without freezing the plant material in liquid nitrogen prior to grinding; better results were obtained from frozen material, probably due to more effective fractionation of the tissue. After the enzymes were extracted and absorbed onto paper wicks, the latter were stored in a deep-freeze at $-70^{\circ} \mathrm{C}$ until use. Electrophoretic separation of 
enzyme variants was accomplished on 12 per cent horizontal starch gels in either a discontinuous $0 \cdot 2 \mathrm{M}$ tris-citrate/lithium borate buffer system at $p \mathrm{H} 8.3(A D H, A C P, G O T, M O H, P G I)$ or a continuous $0.065 \mathrm{M}$ histidine buffer at $p \mathrm{H} \mathrm{5.7}\left(E S T_{f l}\right.$, PER, PGM, SOD) (Cardy et al., 1983).

Approximately 20 enzyme systems were tested for activity, and scorably distinct bands were obtained for 8: acid phosphatase $(A C P)$, alcohol dehydrogenase $(A D H)$, fluorescent esterase $\left(E S T_{f l}\right)$, glutamate oxaloacetate transaminase $(G O T)$, peroxidase $(P E R)$, phosphoglucosisomerase $(P G I)$, phosphoglucomutase (PGM), and superoxidedismutase (SOD). Scorable bands were obtained from some individuals for malate dehydrogenase $(M D H)$ but the amount of activity was too inconsistent to provide scorable results. Staining of enzymes was according to recipes slightly modified from Shaw and Prasad (1970) except for $E S T_{f l}$, for which the staining schedule of Soltis et al. (1983) was followed.

\section{RESULTS}

Six out of the eight enzyme systems studied were polymorphic in at least one of the three collection localities (table 1; table 2). Only GOT and SOD were monomorphic within each site and were fixed for the same allele at all three sites. The same PER band was present in all of the 220 individuals sampled except one from New Hope Creek which expressed a slower band. This individual was also unique with regard to its PGM phenotype, expressing a band not found elsewhere. Two enzymes ( $A C P$ and $E S T_{f l}$ ) were monomorphic at the Eno River locality but were polymorphic at New Hope Creek and Flat River. The $A C P$ band fixed at the Eno River locality was also present at New Hope Creek and Flat River, and a second $A C P$ band present at the latter sites was the same at both sites.
Table 1 Summary of electrophoretic variability in $C$. americanum by enzyme system and locality. $\mathrm{M}=$ monomorphic; $\mathrm{P}=$ polymorphic. Numbers in parentheses indicate the number of different bands present among individuals in populations for a given enzyme system

\begin{tabular}{llll}
\hline & Eno River & New Hope Creek & Flat River \\
\hline$A D H$ & $\mathrm{P}(2)$ & $\mathrm{M}$ & $\mathrm{P}(2)$ \\
$A C P$ & $\mathrm{M}$ & $\mathrm{P}(2)$ & $\mathrm{P}(2)$ \\
$G O T$ & $\mathrm{M}$ & $\mathrm{M}(8)$ & $\mathrm{M}$ \\
$P G I$ & $\mathrm{P}(8)$ & $\mathrm{P}(8)$ & $\mathrm{P}(8)$ \\
$E s t_{\text {f }}$ & $\mathrm{M}$ & $\mathrm{P}(2)$ & $\mathrm{P}(3)$ \\
$P E R$ & $\mathrm{M}$ & $\mathrm{P}(2)$ & $\mathrm{M}$ \\
$P G M$ & $\mathrm{P}(3)$ & $\mathrm{P}(4)$ & $\mathrm{P}(3)$ \\
$S O D$ & $\mathrm{M}$ & $\mathrm{M}$ & $\mathrm{M}$ \\
\hline
\end{tabular}

The single $E S T_{f}$ band present at Eno River was also present at the other two localities. A second $E S T_{f}$ band was present at both Flat River and New Hope Creek localities, and a third, much faster, band was expressed in three individuals (out of 60) from the Flat River. $A D H$ was monomorphic at New Hope Creek but was polymorphic at the Eno and Flat River localities. Plants at the latter two localities expressed the same band as was present at New Hope Creek, plus a second band in common between the two localities where $A D H$ was polymorphic. Any given individual expressed only one band for these enzymes.

$P G I$ and $P G M$ were both polymorphic at all three sites. Up to eight $P G I$ bands were expressed in individuals from the three sites although all were not scorable in every individual. Variation in $P G I$ was noted in two sets of bands on the gel. A slowly migrating pair of bands exhibited variation, but were too indistinct to be scored consistently; among faster migrating bands, individual plants expressed either band 3 or band 5 , but never both. In the present analysis, bands 3 and 5 of $P G I$ were interpreted as allelic variation at a single locus. PGM consistently expressed two bands per individual (fig. 2), one of which was monomorphic

Table 2 Allele frequencies for polymorphic enzyme loci in Climacium americanum. Sample sizes $(N)$ vary due to uneven scorability of gels

\begin{tabular}{|c|c|c|c|c|c|c|c|c|c|c|c|c|}
\hline \multirow[b]{2}{*}{ enzyme } & \multicolumn{4}{|c|}{ Eno River } & \multicolumn{4}{|c|}{ New Hope Creek } & \multicolumn{4}{|c|}{ Flat River } \\
\hline & $N$ & alleles & & & $N$ & alleles & & & $N$ & alleles & & \\
\hline$A D H$ & 40 & 0.58 & 0.42 & & 40 & $1 \cdot 00$ & - & & 37 & $0 \cdot 35$ & 0.65 & \\
\hline${ }^{*} A C P$ & - & & & & 37 & $0 \cdot 46^{1}$ & $0 \cdot 54^{2}$ & & 39 & $0 \cdot 74^{1}$ & $0 \cdot 26^{2}$ & \\
\hline$E S T_{f}$ & 120 & - & $1 \cdot 00$ & - & 17 & - & 0.41 & 0.59 & 59 & 0.05 & $0 \cdot 24$ & 0.71 \\
\hline${ }^{*} P G I$ & 100 & $0 \cdot 58^{2}$ & $0.42^{1}$ & & 20 & $0 \cdot 60^{2}$ & $0 \cdot 40^{1}$ & & 58 & $0 \cdot 29^{2}$ & $0 \cdot 71^{1}$ & \\
\hline${ }^{*} P G M$ & 120 & $0 \cdot 50^{1}$ & - & $0 \cdot 50^{2}$ & 40 & $0.35^{1}$ & 0.05 & $0 \cdot 60^{2}$ & 60 & $0.40^{1}$ & $0 \cdot 60^{2}$ & \\
\hline
\end{tabular}

* Allelic variation at these loci correspond to morphological differentiation between C. americanum var. americanum (1) and var. kindbergii (2) (see table 3). 


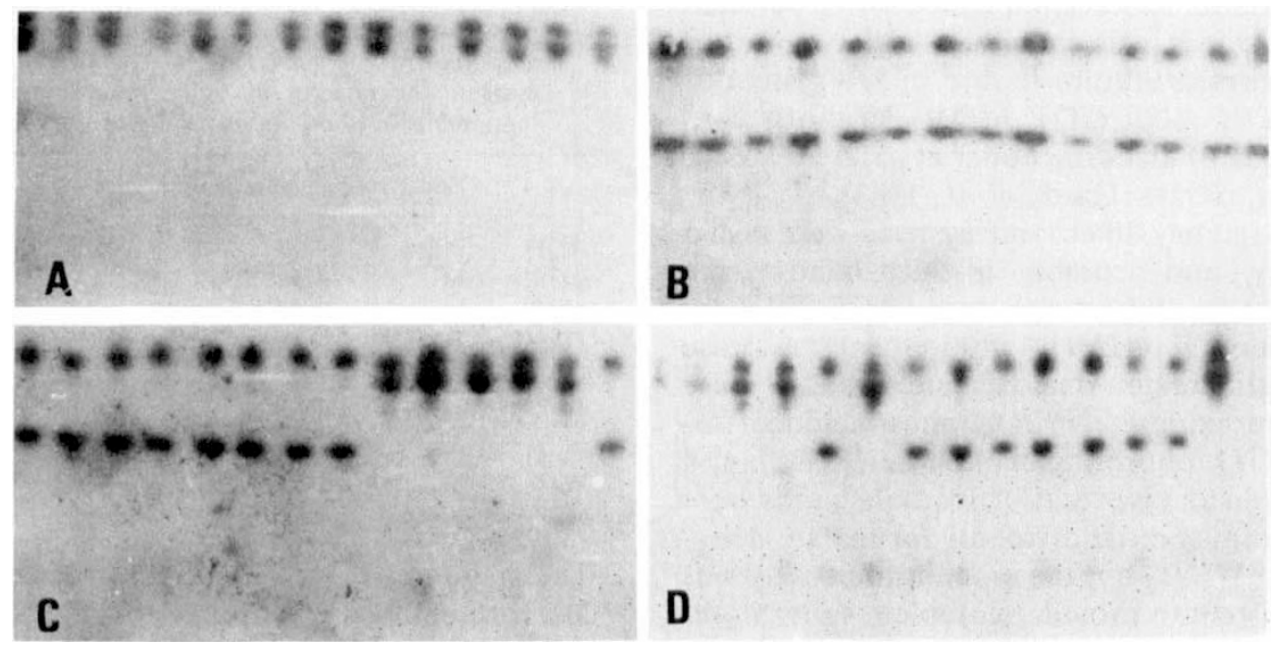

Figure 2 Phosphoglucomutase banding patterns in the var. americanum and var. kindbergii. The lanes correspond to consecutive collections along transects. A. Eno River; all var. kindbergii. B. Eno River; all var. americanum. C. Flat River. D. New Hope Creek. At the last two localities both varieties were encountered along the same transects.

across all three populations and the other showed three variants which were interpreted as alleles at a single locus.

Linkage disequilibrium coefficients (Roughgarden, 1979) among the enzyme loci scored showed striking genetic differentiation between Climacium americanum var. kindbergii and var. americanum (table 3 ). In the estimation of linkage disequilibrium $(D)$, the following assumptions and adjustments were made: allelic variants that occurred in fewer than 3 individuals $\left(E S T_{f l}\right.$ allele 1 and PGM allele 2) were not included and morphological variants were assigned numerical allelic scores of 1 for dendroid (var. americanum) and 2 for nondendroid (var. kindbergii). Estimates of $D$ can range from 0 for no association to a maximum value of 0.25 for complete association between alleles at different loci. The strongest associations between observed morph and enzyme variation were shown by $P G I$ and $P G M$. For both of these enzymes, there was almost a complete correspondence between enzyme banding pattern and morphological variation (fig. 2). There was also a strong association betweeen $A C P$ alleles and morph; and, where there was sufficient sampling and variation to estimate $D$ for $A D H$ (Flat River), a weaker still significant association between $A D H$ alleles and morph type. The only enzyme for which variation was observed that did not show allelic association with morphological types was $E S T_{f}$.

Table 3 Linkage disequilibrium coefficients (D) among loci assayed (sample sizes in parentheses). $G^{2}$ statistics (Bishop et al., 1975 ) for tests of significance of $D$ are also shown. All $G^{2}$ values are based on 2-way tabulations of allelic variation between pairs of loci and hence have 1 degree of freedom

\begin{tabular}{|c|c|c|c|c|c|c|c|c|c|c|c|c|}
\hline & \multicolumn{3}{|c|}{ Eno River } & \multicolumn{4}{|c|}{ New Hope Creek } & \multicolumn{5}{|c|}{ Flat River } \\
\hline & & $P G M$ & $P G I$ & $A C P$ & $E S T$ & $P G M$ & $P G I$ & $A C P$ & $A D H$ & $E S T$ & $P G M$ & $P G I$ \\
\hline$A D H$ & $\begin{array}{l}D_{2} \\
G\end{array}$ & & & & & & & $\begin{array}{l}0 \cdot 16(17) \\
10 \cdot 0^{* * *}\end{array}$ & & & & \\
\hline$E S T$ & $\begin{array}{l}D_{2} \\
G\end{array}$ & & & $\begin{array}{r}0 \cdot 17(17) \\
12 \cdot 2^{* * *}\end{array}$ & & & & - & $\begin{array}{l}0 \cdot 10(37) \\
7 \cdot 7^{* *}\end{array}$ & & & \\
\hline$P G M$ & $\begin{array}{l}D_{2} \\
G\end{array}$ & & & $\begin{array}{c}0 \cdot 21(36) \\
32 \cdot 3^{* * *}\end{array}$ & $\begin{array}{c}0.24(17) \\
23 \cdot 0^{* * *}\end{array}$ & & & $\begin{array}{l}0 \cdot 15(39) \\
21 \cdot 4^{* * *}\end{array}$ & $\begin{array}{l}0.09(37) \\
9 \cdot 3^{* * *}\end{array}$ & $\begin{array}{l}0.04(56) \\
1.6 \text { n.s. }\end{array}$ & & \\
\hline$P G I$ & $\begin{array}{l}D_{2} \\
G\end{array}$ & $\begin{array}{c}0.23(106) \\
118 \cdot 5^{* * *}\end{array}$ & & $\begin{array}{c}0 \cdot 18(19) \\
12 \cdot 4^{* * *}\end{array}$ & $\begin{array}{c}0 \cdot 17(17) \\
12 \cdot 2^{* * *}\end{array}$ & $\begin{array}{l}0 \cdot 19(19) \\
15 \cdot 5^{* * *}\end{array}$ & & $\begin{array}{l}0.09(38) \\
9.9^{* * *}\end{array}$ & $\begin{array}{l}0.06(37) \\
3.5 \text { n.s. }\end{array}$ & $\begin{array}{l}0.02(55) \\
0.8 \text { n.s. }\end{array}$ & $\begin{array}{c}0 \cdot 13(58) \\
18 \cdot 9^{* * *}\end{array}$ & \\
\hline morph & $\begin{array}{l}D_{2} \\
G\end{array}$ & $\begin{array}{c}0 \cdot 25(120) \\
166 \cdot 4^{* * *}\end{array}$ & $\begin{array}{l}0.23(100) \\
118 \cdot 5^{* * *}\end{array}$ & $\begin{array}{c}0.23(36) \\
41 \cdot 4^{* * *}\end{array}$ & $\begin{array}{c}0 \cdot 20(16) \\
14 \cdot 5^{* * *}\end{array}$ & $\begin{array}{l}0.22(37) \\
37 \cdot 0^{* * *}\end{array}$ & $\begin{array}{l}0 \cdot 21(19) \\
19 \cdot 0^{* * *}\end{array}$ & $\begin{array}{c}0 \cdot 11(39) \\
11 \cdot 4^{* * *}\end{array}$ & $\begin{array}{l}0 \cdot 08(37) \\
8 \cdot 1^{* * *}\end{array}$ & $\begin{array}{l}0.02(56) \\
0.4 \text { n.s. }\end{array}$ & $\begin{array}{c}0 \cdot 17(60) \\
33 \cdot 6^{* * *}\end{array}$ & $\begin{array}{l}0.08(58) \\
8.3^{* * *}\end{array}$ \\
\hline
\end{tabular}




\section{DISCUSSION}

Enzyme variability demonstrated in this study by starch gel electrophoresis provides strong evidence for the presence of genetic variation in Climacium americanum both within and among localities. Variability in enzyme expression can include differences among alleles at a single locus (allozymic variability) and differences in the loci that are expressed (isozymic variability). To distinguish these sources of variation requires a genetic analysis involving electrophoretic studies of parents and their offspring. Climacium rarely undergoes sexual reproduction, so that genetic analyses of this type are not feasible. Consequently, tentative genetic interpretations of banding patterns were based on observed variation in natural populations.

In spite of ambiguities concerning the genetic basis of observed enzyme variation in Climacium, our study has demonstrated a surprising degree of variation within and among localities. Sexual reproduction, as indicated by the production of sporophytes, appears to be extremely rare in Climacium americanum throughout its range (Crum and Anderson, 1981). Bedford (1938) found that in $C$. dendroides, where sporophyte production is also very rare, most natural populations express exclusively female sexuality and fertilisation occurs only in those infrequent populations which are functionally bisexual. Bedford experimentally induced sexual reproduction by transplanting male gametophytes into a population of female gametophytes. Whether such unisexual populations contain genetically male plants that produce no gametangia, has not been determined.

Our field surveys have revealed few instances of sexual reproduction in C. americanum in North Carolina. Although the species is common, sporophytes have been found at only five localities, and in each case only two to five sporophytes occurred in a given population. Moreover, sexual reproduction was restricted to the non-dendroid morphological type occurring on rocks in small streams. We have not seen any sporophytes on plants corresponding to the var. americanum in North Carolina. During the fall of 1984, sporophytes occurred on a few plants in one clump of var. kindbergii from our Eno River collection locality, but sporophytes have not been observed at the two other sites included in this study. We found no more variation among plants at the Eno River locality where sexual reproduction is known to have occurred recently than at other localities.
The rarity of sexual reproduction in $C$. americanum raises the question of the origin of the genetic variation found in this study. There have been a number of recent studies of genetic variation in asexually reproducing plants with the surprising result that such species contain significant levels of variation. Jeffries and Gottlieb (1983) found 39 enzyme phenotypes among clones of the sterile triploid Puccinellia $\times$ phyganodes in arctic North America. Christensen et al. (1982) and Ellstrand and Levin (1982) likewise demonstrated considerable variation in Oenothera laciniata, a permanent translocation heterozygote. Clones of Taraxacum officinale have been shown by several workers to have variable enzyme phenotypes. Usberti and Jain (1978) compared asexual and sexual populations of Panicum maximum and found that sexual lines had higher coefficients of variation for morphological characters and higher levels of allozyme polymorphism, but they found no significant differences in the levels of withinpopulation variation. Estimates of heritability (based on parent-offspring regression) were not higher for asexual species. Krzakowa (1977) and Krzakowa and Szweykowski (1979) found significant levels of peroxidase variation in the liverwort, Plagiochila asplenioides, a species that is asexual over much of its range. Daniels (1982) also found higher levels of variation in three enzymes $(A C P, E S T, P E R)$ within and among British populations of Sphagnum pulchrum, in spite of an apparent absence of sexual reproduction in the populations. Most explanations for the presence of such variation in asexually reproducing plants involves hypothesizing multiple colonisation of sites by different genotypes. Ellstrand and Levin (1982) suggested that Oenothera laciniata may be polyphyletic. Daniels (1982) suggested that variation in Sphagnum pulchrum has been retained from some hypothetical time in the past when sexual reproduction was more common.

The correlation between enzyme phenotypes and morphology indicates the presence of a strong linkage disequilibrium between the genes coding for these enzymes and the genes that control the mode of branching, leaf shape, and leaf areolation in $C$. americanum. Linkage disequilibrium, the nonrandom association of alleles at different loci (technically in the gametes, but in bryophytes, in the gametophyte generation) can have several causes. Disequilibrium may be the result of physical linkage among the genes, the founding of a population by a few colonisers, associative overdominance, or by selection acting on favourable 
epistatic gene interactions (Lewontin, 1974). Linkage disequilibrium resulting from physical linkage or a founder event is expected to decrease over time as a result of recombination, but selection, either directly on the loci under consideration, or by associative overdominance, can maintain the disequilibrium in a stable state over long time periods. The infrequency of sexual reproduction in general, and in particular the apparent extreme rarity of recombination between the vars. kindbergii and americanum, indicate that linkage disequilibrium between enzyme loci and those controlling morphology are maintained by a combination of a founder effect and a lack of inter-varietal recombination. Those cases in which the disequilibrium appeared to break down (i.e., when there was recombination between morphological and enzyme phenotypes) may be due either to sexual recombination between the two varieties of $C$. americanum, or to an incorrect field determination of the variety made on the basis of morphology. When the three enzyme systems of a particular individual fit the common pattern of disequilibrium but are out of phase with our morphological determination, the second explanation is suggested. Other cases may be the result of sexual recombination.

An alternative explanation for the linkage disequilibrium we observed is that the enzyme variants we assayed are not selectively neutral (or are closely linked to genes that affect fitness). It might be argued that the two forms of $C$. americanum occupy distinct habitats and that recombinant genotypes are strongly selected against. However, we consider this explanation to be extremely unlikely. Although in general, the nondendroid plants occupy wetter sites than dendroid plants, in many cases the two occur in sites that appear indistinguishable. This is reflected in our collection of both forms along transects at the New Hope Creek and Flat River localities. There was no obvious ecological differentiation between the two growth forms at these sites. Moreover, selection against recombinants would have to be extraordinarily intense to explain the levels of linkage disequilibrium we observed. If favourable epistatic gene interactions were the cause of the strong disequilibrium (e.g., Mitton and Koehn, 1973), it would be very surprising that precisely the same nonrandom association of alleles was observed at three localities, each a part of a different drainage system.

The systematic significance of these results is that the genetic data suggest that plants corresponding to the var. kindbergii in one locality are more related to plants of var. kindbergii at another locality than they are to plants of the var. americanum at the same locality. This suggests that the kindbergii populations sampled in this study are monophyletic and the results are not consistent with the view that the non-dendroid (kindbergii) morphology is an induced modification of the dendroid morphology influenced by the environment. Nor are our results consistent with a view that the var. kindbergii is a genetically differentiated ecotype of $C$. americanum that has arisen polyphyletically in wet, stream habitats. Whether our results hold over a broader part of the geographic range of $C$. americanum is yet to be determined.

Although published studies are still relatively few, there is reason to believe that electrophoretic data provide valuable insights into systematic problems in bryophytes. Szweykowski and Krzakowa (1979) studied variation in PER, EST, $G O T$, and $G D H$ in 20 Polish populations of the liverwort Conocephalum conicum and found nine patterns of banding for the four enzymes. As a result of linkage disequilibrium, they could reduce the variation to two or three recurring enzyme phenotypes. Szweykowski and Krzakowa found that enzyme phenotypes correlated with morphological races of $C$. conicum and thus their results are much like those reported here.

Krzakowa (1977) studied peroxidase variation in four species of the liverwort genus Pellia and found that each species could be characterised by its enzyme phenotype. In addition, Krzakowa found three populations that were morphologically similar to $P$. endiviifolia but which expressed a unique enzyme phenotype. DeVries et al. (1983) investigated eight enzyme systems of Racopilum spectabile and $R$. cuspidatum in the only electrophoretic study to date on a tropical bryophyte. They estimated a genetic distance of 0.672 between species but the estimate was based on a total of only 59 plants. There have also been a number of other recent electrophoretic investigations of infraspecific variation in bryophytes (e.g., Cummins and Wyatt, 1981; Daniels, 1982; Krzakowa, 1977; Zielinski, 1984a, b, 1986; Zielinski et al., 1985).

The most recent checklist of the mosses of North America (Crum et al., 1973) listed Climacium kindbergii as a synonym of $C$. americanum. Our results, however, coupled with morphological data, suggest that $C$. kindbergii is distinct and should probably be disinguished either at the varietal or specific level. Shaw (in press) found that when transplanted into a greenhouse, the vars. kindbergii and americanum exhibit different modes of growth. Erect, dendroid 
branches of var. americanum appear to be determinate in growth and new growth of plants transplanted into a greenhouse occurs by the origin of new dendroid branches from the underground rhizomatous main stems. That is, already formed branches do not exhibit renewed growth. In contrast, when $C$. kindbergii is transplanted into a greenhouse, existing branches produce new growth from their apices and from the apices of their lateral branches. When grown under non-aquatic conditions, new growth produced by these plants is often more dendroid in form than field-grown portions of the same plants. However, they rarely become as dendroid as plants of the var. americanum grown in the field (Shaw, in press). In order to assess the taxonomic status of $C$. americanum and $C$. kindbergii it would be desirable to extend the electrophoretic study reported here over a broader geographic range, and to further investigate the morphological variation by reciprocal transplant studies done in the field.

\section{REFERENCES}

BEDFORD, T. H. B. 1938. Sex distribution in colonies of Climacium dendroides W. \& M. and its relation to fruit bearing. NW Nat., 13, 213-221.

BISHOP, Y. M. M., FEINBERG, S. E. AND HOLLAND, P. W. 1975. Discrete multivariate analysis: theory and practice, MIT Press, Cambridge, Mass.

CARDOT, J. AND THERIOT, I. 1904. New or unrecorded mosses of North America, II. Bot. Gaz., 37, 363-382.

CARDOT, J. AND THERIOT, I. 1906. New or unrecorded mosses of North America. Bryologist, 9, 6-10.

CARDY, B. J., STUBER, C. W. AND GOODMAN, M. M. 1983. Techniques for starch gel electrophoresis of enzymes from maize (Zea mays L.). Institute of Statistics Mimeo Series No. 1317. North Carolina State University, Raleigh, NC. $35 \mathrm{pp}$.

CHRISTENSEN, B., BERG, M. AND JELNES, J. 1982. Genotypic diversity in Oenothera laciniata (Onagraceae), a permanent translocation heterozygote. Evolution, 36, 63-69.

CRUM, H. A. AND ANDERSON, L. E. 1981. Mosses of Eastern North America, Columbia Univ. Press, New York.

CRUM, H. A., W. C. STEERE AND ANDERSON, L. E. 1973. A new list of mosses of North America north of Mexico. Bryologist, 76, 85-130.

CUMMINS, H. AND WYATT, R. 1981. Genetic variability in natural populations of the moss Atrichum angustatum. Bryologist, 84, 30-38.

DANIELS, R. E. 1982. Isozyme variation in British populations of Sphagnum pulchrum (Braithw.) Warnst. J. Bryol., 12, $1-11$.

DEVRIES, A., VAN ZANTEN, B. O. AND VAN DIJK, H. 1983. Genetic variability within and between populations of two species of Racopilum (Racopilaceae, Bryopsida). Lindbergia, 9, 73-80.
ELLSTRAND, N. C. AND LEVIN, D. A. 1982. Genotypic diversity in Oenothera laciniata (Onagraceae), a permanent translocation heterozygote. Evolution, 36, 63-69.

GRoUT, A. J. 1901. Climacium Web. \& Mohr., Iter. Suec. 96. 1804. Bryologist, 4, 54.

HORTON, D. G. AND VITT, D. H. 1976. Morphological characters, relative to distribution, and taxonomic considerations of the genus Climacium. Can. J. Bot., 54, 1872-1883.

JEFFRIES, R. J. AND GOTTLIEB, L. D. 1983. Genetic variation within and between populations of the asexual plant Puccinellia $\times$ phyganodes. Can. J. Bot., 61, 774-779.

KELLEY, W. A. AND ADAMS, R. P. 1977. Preparation of extracts from Juniper leaves for electrophoresis. Phytochemistry, 16, 513-516.

KRZAKOWA, M. 1977. Isoenzymes as markers of inter- and intraspecific differentiation in hepatics. Bryophyt. Biblio., $13,427-434$

KRZAKOWA, M. AND SZWEYKOWSKI, J. 1979. Isoenzyme polymorphism in natural populations of a liverwort Plagiochila asplenioides. Genetics, 93, 711-719.

LEWONTIN, R. C. 1974. The Genetic Basis of Evolutionary Change, Columbia University Press, New York.

MITTON, J. B. AND KOEHN, R. K. 1973. Population genetics of marine Pelecypods. III. Epistasis between functionally related isozymes of Mytilus edulis. Genetics, 73, 489-496.

RENAULD, F. AND CARDOT, J. 1890. New mosses of North America. IV. Bot. Gaz., 15, 57-62.

ROUGHGARDEN, J. 1979. Theory of population genetics and ecology: an introduction, MacMillan Publishing Co., Inc.; New York.

SHAW, J. 1987. Growth form variation within and among populations of Climacium americanum Brid. Acta Bot. Hung. (in press).

SHAW, D. R. AND PRASAD, R. 1970. Starch gel electrophoresis of enzymes-a compilation of recipes. Biochem. Gen.; 4, 297-320.

SOLTIS, D. E., HAUFLER, C. H., DARROW, D. C. AND GASTONY, G. J., 1983. Starch gel electrophoresis of ferns: a compilation of grinding buffers, gel and electrode buffers, and staining schedules. Am. Fern. J., 73, 9-27.

SZWEYKOWSKI, J. AND KRZAKOWA, M. 1979. Variation of four enzyme systems in Polish populations of Conocephalum conicum (L.) Dum. (Hepaticae, Marchantiales). Bull. Acad. Polon. Sci., Ser. Sci. Biol., 27, 37-41.

USBERTI, J. A. AND JAIN, S. K. 1978. Variation in Panicum maximum: a comparison of sexual and asexual populations. Botanical Gazette, 139, 112-116.

ZIELINSKI, R. 1984a. Genetic variation and evolution of the liverwort genus Pellia with special reference to Central European territory. I. Electrophoretic evidence of crossfertilization in the monoecious Pellia epiphilla, $n=9 . J$. Hattori Bot. Lab., 56, 255-262.

ZIELINSKI, R. 1984b. Genetic variation and evolution of the liverwort genus Pellia with special reference to Central European territory. II. Electrophoretic and cytological study of the Pellia epiphylla and P. borealis complex. $J$. Hattori Bot. Lab., 56, 263-269.

ZIELINSKI, R. 1986. Cross-fertilization in the monoecius Pellia borealis, $n=18$, and spatial distribution of two peroxidase genotypes. Heredity 56, 299-304.

ZIELINSKI, R., SZWEYKOWSKI, J. AND RUTKOWSKA, E. 1985. A further electrophoretic study of peroxidase isoenzyme variation in Pellia epiphylla (L.) Dum. from Poland, with special reference to the status of Pellia borealis Lorbeer. Monogr. Syst. Bot. Missouri Bot. Gard., 11, 199-209. 